\title{
Geographic patterns in the distribution of Palearctic songbirds
}

\author{
Cees S. Roselaar · Ronald Sluys · Mansour Aliabadian • \\ Peter G. M. Mekenkamp
}

Received: 22 July 2005/Revised: 17 December 2005/Accepted: 20 November 2006/Published online: 6 April 2007

(C) Dt. Ornithologen-Gesellschaft e.V. 2007

\begin{abstract}
A database was created of digitized equal area distribution maps of 3,036 phylogenetic species of Palearctic songbirds. Biogeographic patterns are reported for two data sets: (1) including all passeriform bird species reported as breeding within the boundaries of our study map, (2) passeriform species restricted in their distribution to our study region, thus excluding the partly extra-limital taxa. With respect to the data set excluding partly extralimital taxa, the average range size is 238 grid cells (grid cell area: $4,062 \mathrm{~km}^{2}$ ). Analysis of the geographic distribution of species richness for the full data set showed several hotspot regions, mostly located in mountainous areas. The index of range-size rarity identified similar hotspot regions as that for species richness, albeit that the range-size rarity de-emphasized the central Siberian hotspot. Range-size rarity hotspots that are not evident on the measure of species richness concern a great number of islands. Much more prominent on the index of range-size rarity are the Atlas Mountains of northern Africa, the Jabal al Akhdar region in NE Libya, and the eastern border of the Mediterranean. Restricting the analysis of geographic
\end{abstract}

Electronic supplementary material The online version of this article (doi:10.1007/s10336-007-0129-1) contains supplementary material, which is available to authorized users.

Communicated by C. Rahbek.

C. S. Roselaar $\cdot$ R. Sluys $(\bowtie) \cdot$ M. Aliabadian

Institute for Biodiversity and Ecosystem Dynamics,

Zoological Museum, University of Amsterdam,

P.O. Box 94766, 1090 GT Amsterdam, The Netherlands

e-mail: sluys@science.uva.nl

P. G. M. Mekenkamp

Cartography, Faculty of Geosciences, Utrecht University,

P.O. Box 80115, 3508 TC Utrecht, The Netherlands variation to the $25 \%$ of the species with smallest ranges resulted in a greatly simplified pattern of hotspots.

Keywords Passeriformes - Palearctic - Biogeography · Spatial analysis $\cdot$ Hotspots

\section{Introduction}

The Palearctic Region as proposed by Wallace (1876) is currently widely accepted as a natural subdivision of the biosphere (cf. Schmidt 1954), comprising a large section of the globe; it extends from Iceland to Kamchatka, with its southern border approximately located at the Tropic of Cancer $\left(23.5^{\circ} \mathrm{N}\right)$. It should be noted that floristic regions may differ from the zoogeographically based SclaterWallace system (cf. Good 1974; Cox 2001). In this study, we accept the Sclater-Wallace Palearctic Region as a biogeographically, and a physical-geographically, identifiable and informative subdivision of the biosphere.

There are now many published works on the distribution of Palearctic birds (Hartert 1903-1922; Hartert and Steinbacher 1932-1938; Vaurie 1959, 1965). However, this information has yet to be compiled and explored. Previous studies have a far more restricted regional scope, and have largely failed to explore the detail with regard to the Russian and Asian parts of the Palearctic Region (Molineux 1930-1931; Voous 1960; Harrison 1982; Cramp 1977-1994). Our study accumulates and synthesizes this information into a data set on the distribution of all species of the entire Palearctic passeriform fauna.

Based on this database, we describe the range-size frequency distribution and patterns of diversity and distribution of Palearctic passeriform birds. We present maps showing the pattern of: (1) species richness of all pas- 
serine birds; (2) species richness of all passerine birds endemic to the Palearctic Region; (3) range-size rarity or narrow endemism scores (cf. Williams et al. 1996a, b, 2000b) of all passerines endemic to the Palearctic; and (4) species richness of the $25 \%$ species with smallest ranges that are endemic to the region. We use the term 'hotspot' to describe the geographic peaks of species richness and endemism (as measured by indices of range-size rarity) for Palearctic songbirds. When we compare our patterns with other studies, the term hotspot will also be used in a more general sense for areas with high scores on any measure.

\section{Methods}

A database was created of digitized distribution maps of the breeding areas for species of Palearctic passeriforms with the help of the computer program WORLDMAP version 4.1 (Williams 2000a). The geographic distributions were interactively plotted on an equal area map of the Palearctic (area: $30^{\circ} \mathrm{W}-170^{\circ} \mathrm{W}, 18^{\circ} 00^{\prime} \mathrm{N}-86^{\circ} 25^{\prime} \mathrm{N}$; equivalent cylinder projection, equidistant on $55^{\circ}$ parallel circle), overlaid by a $1^{\circ}$ longitude grid (grid cell area: $4,062 \mathrm{~km}^{2}$ ). For analytical purposes, we have included the Cape Verde Islands (traditionally considered to form part of the Palearctic) by assigning them a few grid cells in the lower lefthand corner of the map, i.e. by moving their position $3^{\circ}$ northwards. Birds occurring in Greenland, the Philippines, and Alaska were not mapped, as these areas fall outside the Palearctic biogeographic region.

Our database contains many Oriental and Afrotropical species that have their main distribution outside the Palearctic and thus exhibit a range that extends beyond the borders of our map. Such species are here referred to as 'partly extra-limital', where 'extra-limital' indicates species with ranges wholly beyond the area of interest (cf. Cramp 1977-1994). These partly extra-limital species were not treated in the earlier taxonomic studies on the Palearctic avifauna. These species are, however, represented in our database since the southern boundary of our map is located at $18^{\circ} \mathrm{N}$ and not at the more traditional latitude for the Palearctic, viz. $23.5^{\circ} \mathrm{N}$. Omitting these partly extralimital species from our database leaves 2,401 taxa that are restricted in their distribution to the Palearctic Region as well as to the confines of our map.

The construction of the distribution maps was greatly facilitated by a reference guide with 5,000 annotated references, including a gazetteer, on the distribution of Palearctic birds (C.S. Roselaar, in preparation). Distribution maps for each of the taxa and their diagnoses will be published elsewhere (C.S. Roselaar and H. Shirihai, in preparation).
We have chosen the phylogenetic species concept (sensu Cracraft 1983) as our descriptor of species level diversity (see also Sluys and Hazevoet 1999; Sangster et al. 1999; Agapow et al. 2004; Agapow and Sluys 2005). Traditionally, ornithologists have applied the isolation or biological species concept (e.g., Vaurie 1959) and, as a consequence, have recognized a great number of subspecies. In practice, application of the phylogenetic species concept implies that many of these traditional subspecies will be elevated to the rank of full species (cf. Cracraft 1992). Thus, our full database contains 3,036 maps, one for each taxon, i.e. phylogenetic species (see Electronic Supplementary Material for a list of these taxa), contrasting with the 537662 isolation or biological species of passeriforms that are traditionally recognized for the Palearctic. The data for the 3,036 maps consist of 7,99,261 different grid cell presence records in 15,405 grid cells on the map. For the determination of range size, a second, more restricted, database was created by omitting the maps of partly extra-limital species, i.e. species with distributions that transgress the boundaries of our map. This second database contains 2,401 taxa, comprising 6,80,586 different grid cell presence records in 14,714 grid cells.

Since our data were assembled from several sources and sampling effects are inherent in any distributional study, it is important to distinguish between unrecorded presences of a species and true absences. For many West European countries, breeding distribution atlases are available, generally presenting the data with codings for "certain breeding," " "probable breeding," " "possible breeding," and true absences. Such atlases are not available for North Africa, European Russia, and many Asiatic countries, and distribution here was assessed by plotting data obtained from specimen labels and primary literature, using four codings: "certain breeding" (nest with eggs or nestlings found) and "probable breeding" (species frequently encountered while singing or displaying in suitable habitat in breeding season), comparable with the same codings in West European breeding atlases. The third type of coding, "inferred breeding," was obtained through interpolation, i.e. by extending the distributional range up to 5 grid squares distant from a "certain" or "probable" data point/ grid cell as far as suitable habitat reached. A fourth coding, "possible breeding," was used for observations or skins obtained in the breeding season in areas for which no suitable habitat is thought to exist and which are remote from "certain" grid cells. In our WORLDMAP analyses, we included the codings "breeding" and "probable breeding," and "inferred breeding", but not that for " "possible breeding." The codings are visualized by separate colours on the individual maps, but are not represented on the summarizing maps presented in this paper. Thus, the procedure followed by us implies that we used two dif- 
ferent sampling regimes, one where we relied on atlases and another one where we assessed the extent of occurrence.

Habitat data were obtained from the detailed map of Dyuzheva (1973) for the former Soviet Union, and from habitat maps in local bird literature for other countries.

We describe patterns of diversity by two measures, viz. species richness and narrow endemism or range-size rarity. Hotspots of species richness are chosen by counting the numbers of species in each grid cell, subsequently ranking the cells by this count, and selecting the higher scoring cells (Williams 2000a). Hotspots of range-size rarity are determined by calculating the sum of the inverse of the range sizes (Williams 2000a). A species recorded from 1 cell has the maximum weight of 1 , a species occurring in 10 cells scores 0.1 , from 100 cells 0.01 , etc. For each grid cell, the weights are added up for all species occurring in this cell. Effectively, this measure gives greater weight to the most restricted species, with the widespread species having little effect on the scores (Williams 2000b).

Terborgh and Winter (1983), Bibby et al. (1992), Long et al. (1996), and Stattersfield et al. (1998) defined as narrow endemics birds with range sizes of less than $50,000 \mathrm{~km}^{2}$ and found that $25-27 \%$ of all analyzed birds fell in this category. However, endemism is a relative concept and therefore we refrained from applying an absolute threshold of range-size and instead identified the rare quartile $(25 \%)$ of species with most restricted distributions, determined by numbers of occupied grid cells (cf. Williams et al. 1996a, 2000a).

For mapping our diversity patterns, we have used both the equal frequency and the equal interval option in WORLDMAP. For the equal interval scale, the different area extents of the various colours on the map show the frequency distribution of the scores as well as their spatial distribution, although this option may reduce discrimination among areas. In contrast, the equal-frequency scale maximizes discrimination among areas on the map (by giving near-equal area to each colour), in some cases giving greater emphasis to some of the smaller differences among scores. Because of its maximal discrimination, higher resolution, we will focus most of our attention on the presentation and discussion of the results obtained with the equal-frequency option.

\section{Results}

\section{Range sizes}

For the database with 2,401 taxa (excluding partly extralimital species) we examined the range sizes among the phylogenetic species. The frequency distribution of the geographic breeding ranges among species shows that the taxa occupy ranges varying from 1 to 5,613 grid cells (Fig. 1). The average range size is 238 grid cells. However, this average is strongly influenced by the relatively few taxa that have an extraordinarily large area of distribution, with only $7 \%$ of the taxa having a range size comprising 1,000 or more grid cells. The effect of these relatively few outliers is illustrated by the fact that $25 \%$ of the taxa have a range size that lies between 1 and 27 grid cells, $50 \%$ of the taxa have an area of distribution covering 1-89 grid cells, and that $75 \%$ of the taxa have a range size that lies mostly near or below the average, in that it varies between 1 and 256 occupied grid cells.

\section{Species richness}

The geographic distribution of species richness among $1^{\circ}$ longitude grid cells in the full data set is shown in Fig. 2a, b. In the equal-frequency analysis (Fig. 2a), a characteristic horseshoe-shaped area with hotspots follows the mountain chain of the Himalayas, extending west to north Pakistan and from thereon north to the Pamir, Alai, and Tien Shan ranges. The other, eastern part of this horseshoe-shaped region of hotspots curves from Yunnan northwards to the mountains fringing the Red Basin of Sichuan and further north to the mountains of southwest Gansu and southern Shaanxi. A large and broad hotspot area extends from Yunnan south through the mountains of Myanmar, Thailand, Laos, and northwest Vietnam.

A major peak in richness is located in central Siberia, comprising a large area formed by the mountains of the Altai-Sayan-Khamar Daban system. Other regions with high levels of richness follow the Elburz Mountain range directly south of the Caspian Sea, curving northwestwards

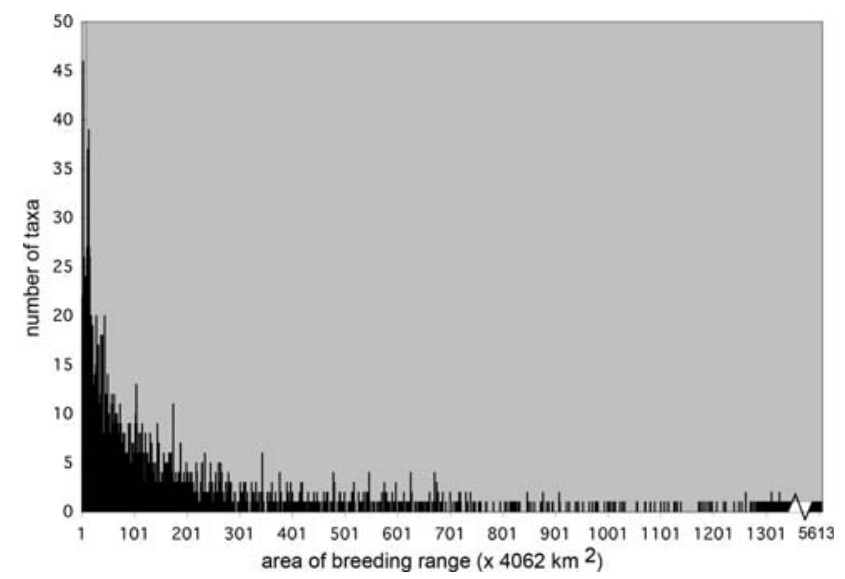

Fig. 1 Frequency distribution of range sizes of Palearctic passerine birds. Taxa examined exclude partly extra-limital species. Range size expressed as number of occupied grid cells on the map, with each cell covering $4,062 \mathrm{~km}^{2}$ 

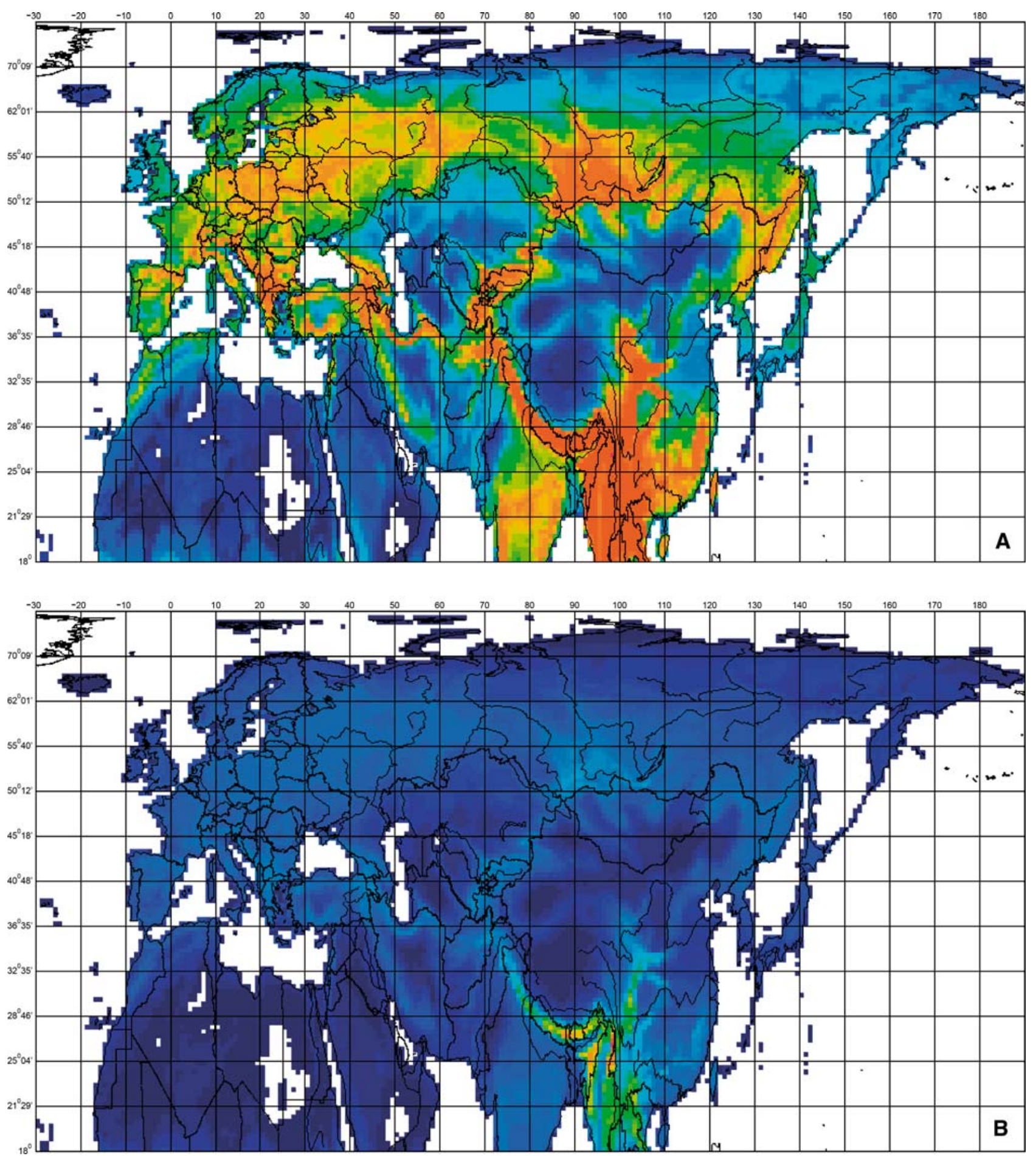

Fig. 2 Map of species richness among equal area grid cells in the full data set (3,036 taxa) of Palearctic songbirds. a Maximum richness shown in deep rufous and minimum in dark blue. Scores grouped into 32 color-scale classes of approximately equal frequency. Classes: 1-3 species per grid cell (blue), 4-5, 6-7, 8-9, 10-12, 13-14, 15-16, 1719, 20-23, 24-26, 27-30, 31-34, 35-38, 39-41, 42-45, 46-49, 50-54, $55-57,58-61,62-64,65-68,69-71,72-73,74-76,77-79,80-81$, 82-83, 84-86, 87-89, 90-98, 99-127, 128-307 (rufous); also a single grid cell with maximum score (316 species, in northeast Myanmar) in red. b Scores grouped into 32 color-scale classes of approximately equal interval. Classes: 1-10 species per grid cell (blue), 11-20, 2130, 31-40, 41-50, 51-60, 61-69, 70-79, 80-89, 90-99, 100-109, 110-119, 120-128, 129-138, 139-148, 149-158, 159-168, 169-178, 179-188, 189-197, 198-207, 208-217, 218-227, 228-237, 238-246, 247-256, 257-266, 267-276, 277-286, 287-294, 295-303, 304-307 (rufous), and one red cell for 316 
towards another species-rich region centered on the Caucasus and the mountains of southern and eastern Turkey, and with the eastern section of the Elburz area via the Kopet Dag mountains almost touching the Hindu Kush extension of the Himalayan region. In Europe, the most species-rich areas are located on the Balkan Peninsula, more or less centred on Macedonia.

When partly extra-limital species are excluded from the analysis, the patterns of geographic variation in species richness remain basically the same, except for the southeastern part of the area (Fig. 3a, b). Since most of the partly extra-limital species occur in the Ethiopian and Oriental Regions, the restricted database de-emphasizes the large hotspot region in Southeast Asia (Myanmar, etc.) found by the full data set.

\section{Range-size rarity}

In some respects, the index of range-size rarity, applied to the restricted data set with 2,401 taxa, gives results similar to the one of species richness in that it also identifies as hotspots the horseshoe-shaped region centering on the Himalayas and the Pamir-Altai-Tien Shan system, the area south of the Caspian Sea, and the Caucasus area (Fig. 4a). On the other hand, the prominent high level of species richness in central Siberia has a low score for the measure of range-size rarity. In addition, the range-size rarity measure also identifies peak regions that are not evident in the species richness map (Fig. 3a). In particular, a great number of islands are highlighted as hotspots for narrowly endemic species, such as the Canaries, Corsica, Sardinia, Cyprus, Taiwan, and Hainan. Islands of considerably larger size, such as Japan and Sakhalin, also score relatively highly on the index of range-size rarity. The island effect is also apparent in the British Isles, since the scores for Ireland and the UK are considerably higher than those for the adjacent continental areas at the same latitude.

However, with respect to this island pattern the following caveat is offered. The island pattern may partly reflect the fact that the range-size rarity score is influenced by the number of species. The rarity-index, therefore, may not be really comparable between grid cells of vastly different number of species. The index will bias islands, which generally have fewer species, to have a relatively higher range-size score than comparable mainland areas that have a basic level of species richness.

Another region that is much more prominent on the measure of range-size rarity corresponds with the Atlas Mountains of NW Africa. Smaller mainland areas that are highlighted are, for example, the Jabal al Akhdar region in northeast Libya, and the eastern border of the Mediterranean.
When the analysis of geographic variation in endemism is restricted to the $25 \%$ species with the smallest ranges (i.e. the first range-quartile; sensu Williams et al. 1996a, 2000a), the pattern of hotspots is more pronounced (Fig. 5a). Regions with high values are again the Himalayas, extending southwards via eastern Assam to the Chin Hills of Myanmar and to the mountains of northeast Myanmar and western Yunnan, as well as Hainan, Taiwan, Corsica, Sardinia, the Canary Islands, and also to a lesser degree the southern border of the Caspian Sea and the eastern border of the Mediterranean. The results presented in Fig. 5a, b are based on the analysis of the data set of species endemic to Palearctic. However, when the analysis is performed on the entire data set, the results are only somewhat different along the southern border of the map.

\section{Discussion}

\section{Effects}

For Afrotropical birds, De Klerk at al. (2002) demonstrated that biogeographical patterns for passerines and nonpasserines are similar. Therefore, we presume that the inclusion of non-passeriforms in our database will have a limited effect on the outcome of the analyses.

\section{Range-size distribution}

It has been established that there is substantial variation in the sizes of geographic ranges of individual species (cf. Brown et al. 1996). In particular, this enormous variation has been well documented for vertebrates, with the frequency distribution of range sizes among species universally taking the shape of a "hollow curve" (Brown 1995; Brown et al. 1996; Gaston 2003), as is the case also in Palearctic passeriforms (Fig. 1). The hollow curve shape implies that most species have rather small ranges and that only a small percentage of species have very large ranges. Anderson (1984) documented this phenomenon for North American birds, and other studies found a similarly skewed range-size distribution for the New World avifauna (Blackburn and Gaston 1996; Gaston and Blackburn 1997), and for parrots (Blackburn et al. 2004).

Comparisons with some other studies

Humphries et al. (1999) and Williams et al. (2000b) explored spatial patterns in a major part of the Western Palearctic for 3,302 vascular plants and in Europe for terrestrial vertebrates (including 445 European breeding birds) plus plants, respectively. The European hotspot areas 

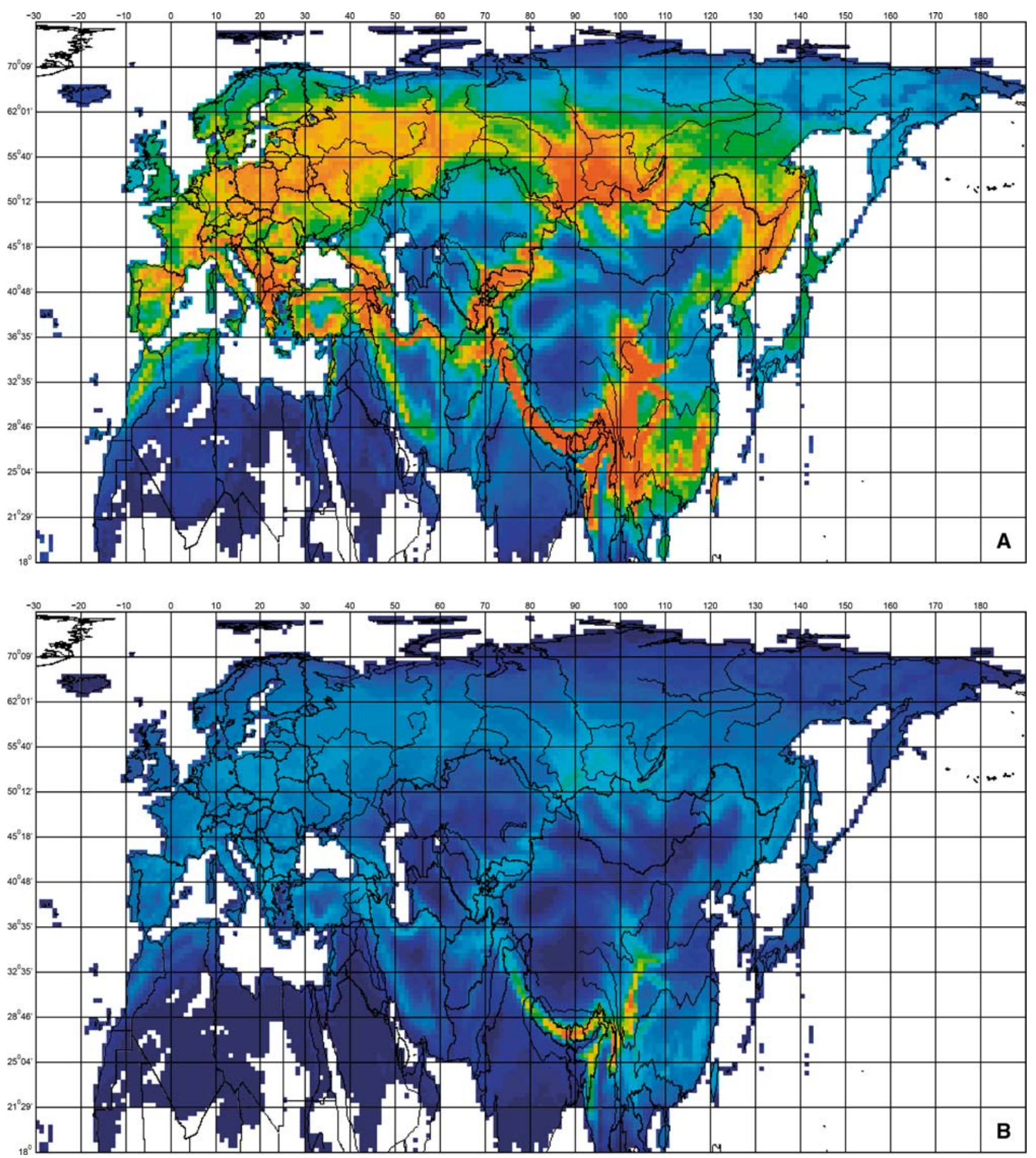

Fig. 3 Map of species richness among equal area grid cells in the data set of Palearctic songbirds excluding partly extra-limital species. a Maximum richness shown in deep rufous and minimum in dark blue. Scores grouped into 32 color-scale classes of approximately equal frequency. Classes: 1 species per grid cell (blue), 2, 3-4, 5, 6-7, 8-10, 11-13, 14-16, 17-19, 20-23, 24-27, 28-30, 31-34, 35-38, 39$41,42-45,46-49,50-53,54-57,58-60,61-63,64-67,68-69,70-72$, $73-75,76-78,79-80,81-83,84-86,87-91,92-104,105-220$ (rufous); also a single grid cell with maximum score (221 species), in red. $\mathbf{b}$ Scores grouped into 32 color-scale classes of approximately equal interval. Classes: 1-7 species per grid cell (blue), 8-14, 15-21, 22-28, 29-35, 36-42, 43-49, 50-55, 56-62, 63-69, 70-76, 77-83, 84-90, 91-97, 98-104, 105-110, 111-117, 118-124, 125-131, 132138, 139-145, 146-152, 153-159, 160-165, 166-172, 173-179, 180186, 187-193, 194-200, 201-207, 208-213, 214-220 (rufous), and one cell in red (221 species) 

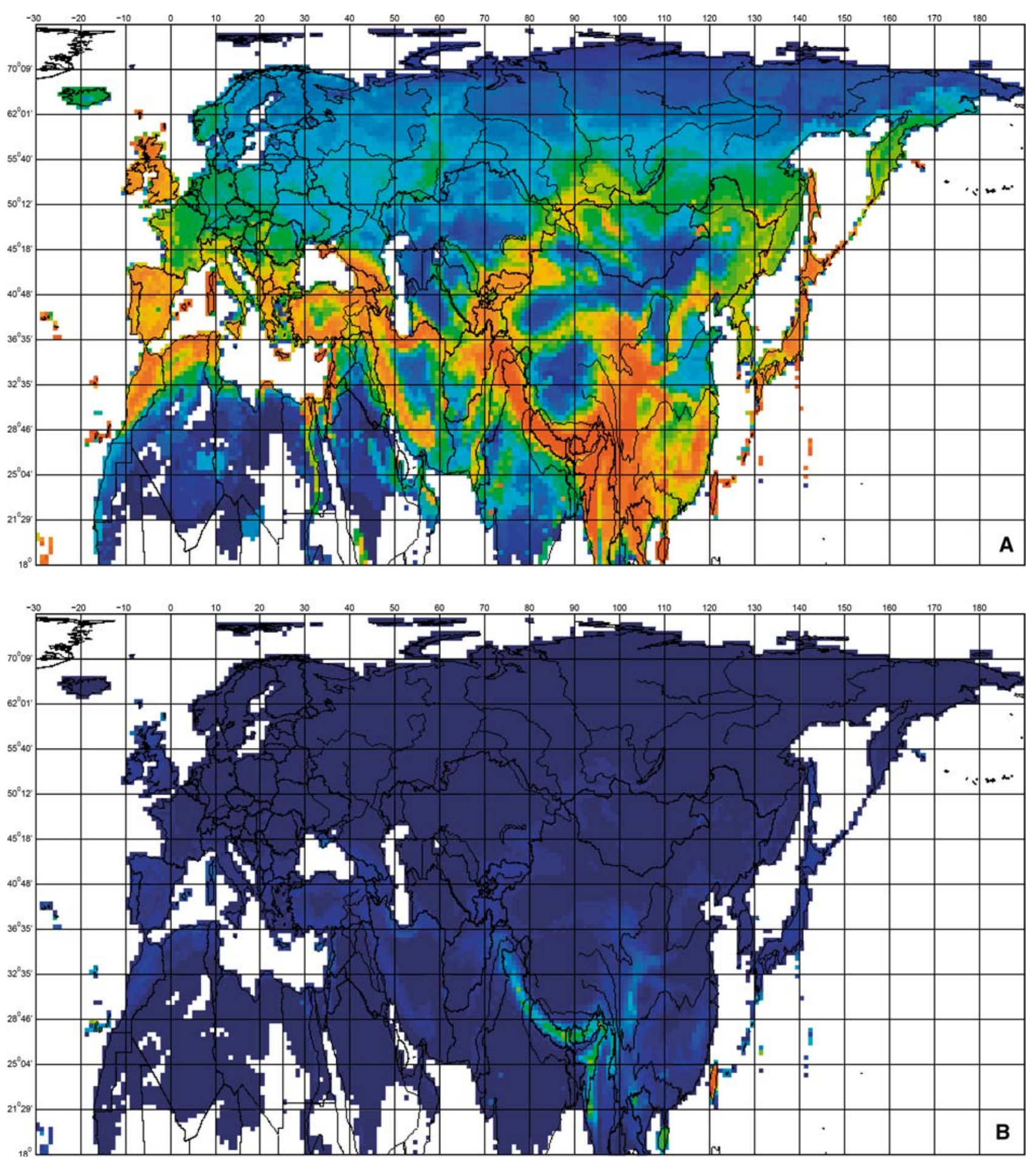

Fig. 4 Map of geographic variation in range-size rarity scores among equal area grid cells in the data set of Palearctic songbirds excluding partly extra-limital species. a Scores are grouped into 33 color-scale classes, each of which contains approximately equal numbers of grid cells on a gliding scale ranging from 0.00 to $4.34 \%$, with a separate single grid cell for the maximum score $(4.35 \%)$. b Scores are grouped into 31 color-scale classes, each of which contains approximately equal numbers of grid cells on a gliding scale ranging from 0.14 to $4.34 \%$, with a separate single grid cell for the maximum score $(4.35 \%)$

the richest areas occur in and around the montane areas of central and southern Europe (Pyrenees, Alps, Carpathians, Stara Mountains), while diversity is low in northern and identified by Humphries et al. (1999) and Williams et al. (2000b) to some extent do match those for the Palearctic passeriforms. For taxon richness, both studies found that 

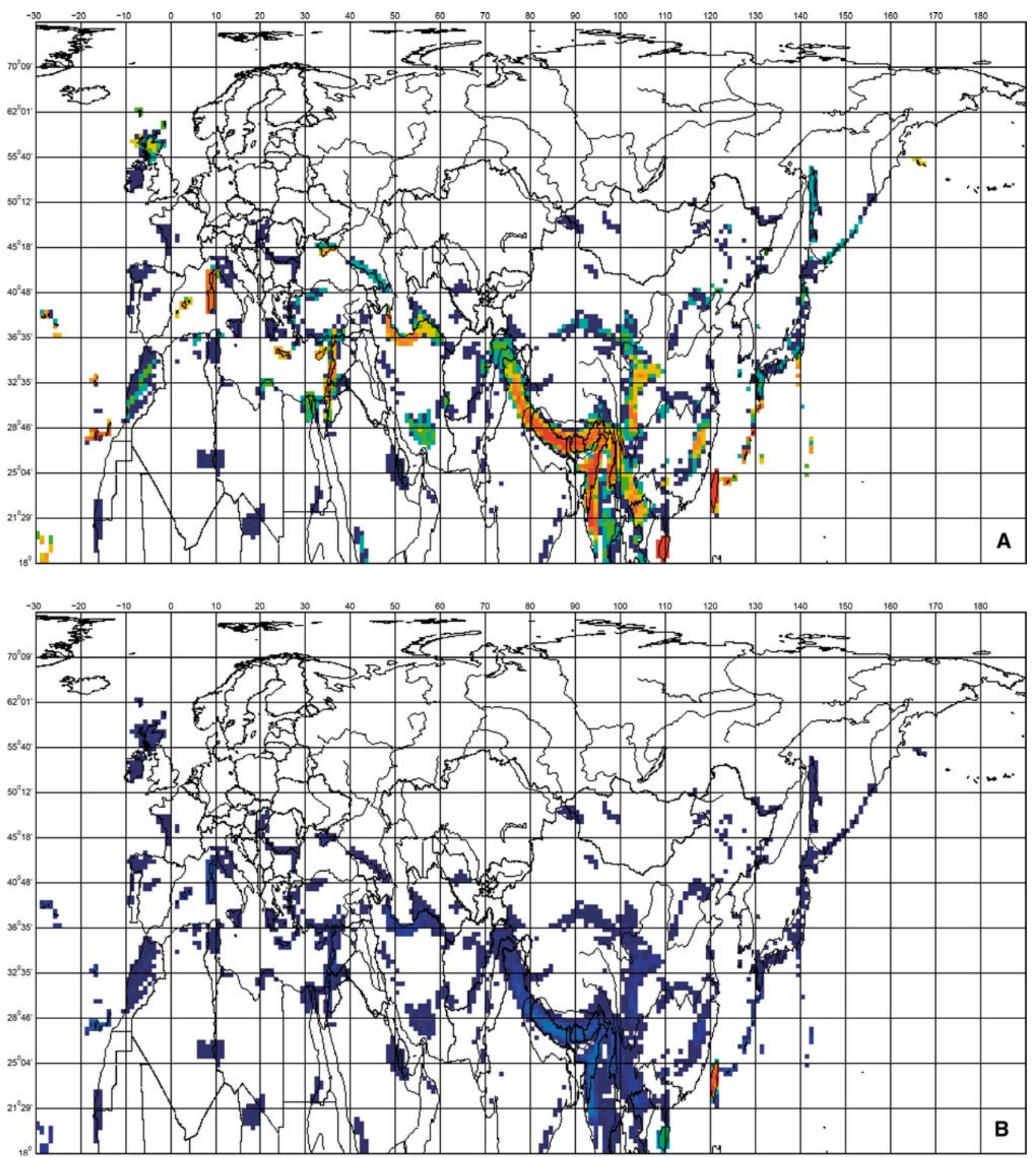

Fig. 5 Map of geographic variation in range-size rarity scores among equal area grid cells for the rare quartile of species with most restricted distributions, determined by numbers of occupied grid cells; partly extra-limital species are excluded. a Scores are grouped into ten color-scale classes, each occurring in about equal frequency. Classes: 1 species in grid cell (blue), 2 species, 3, 4, 5, 6-7, 8, 9-11,
12-15, and 16-64 species (deep rufous); an extra class (in red) for three cells with the highest score ( 65 species, all on Taiwan). b Scores are grouped into 32 color-scale classes, each occurring in about equal interval. Classes: 1-2 species in grid cell (blue), 3-4, 5-6, 7-8, 9-10, etc., to 63-64 species, with an extra class (in red) for cells with the highest score (65 species, all on Taiwan) 
southern Europe, particularly on the Iberian Peninsula (Humphries et al. 1999; Williams et al. 2000b). The pattern for range-size rarity was different in that the emphasis had shifted southwards, so that in addition to the hotspots in the montane regions of Europe (now including the Dalmatians and the mountains of Croatia, Bosnia-Herzogovina, Yugoslavia, Albania, and Greece), hotspots for narrow endemics were located also in southeastern Spain (Sierra Nevada), and the islands of Mallorca, Corsica, and Crete.

By visual inspection, we have compared the patterns of the Palearctic songbirds with the hotspot areas identified by Mittermeier et al. $(1999,2004)$ that fall within the boundaries of our study area. Considerable agreement exists in the selection of the Caucasus, Israel and Lebanon, Tyrrhenian Islands (with the exception that Sicily does not qualify on the Palearctic passeriforms), Cyprus, Crete, the Atlantic Islands, the Libyan "bump," and sections of Morocco and Algeria. With respect to the Mediterranean Basin, our study de-emphasizes Mittermeier's $(1999,2004)$ hotspot areas in southern and central Greece, and in southern Turkey, while it finds no support for the Maritime Alps.

The Indo-Burma region of Mittermeier et al. (1999) in large part conforms to our hotspot region in that part of the world. However, Palearctic songbirds suggest that this hotspot area does not end in Nepal, as suggested in Mittermeier et al. (1999), but extends much farther northwestwards (see Figs. 3a, 4a, 5a), a result that conforms to Mittermeier et al. (2004). The south-central China hotspot region of Mittermeier et al. (1999) and the Mountains of southwest China hotspot of Mittermeier et al. (2004) cover a considerable part of the hotspot region in China suggested by the geographic distribution of Palearctic songbirds.

It is noteworthy that Taiwan did not qualify as a hotspot in the analysis of Mittermeier et al. (1999), whereas the Palearctic passeriforms identify this island as a hotspot on most indices of biodiversity used in the present study. Mittermeier et al. (2004) introduced Taiwan as an area worthy to be incorporated into a global conservation strategy.

\section{Zusammenfassung}

Geographische Muster in der Verbreitung paläarktischer Singvögel

Auf der Grundlage digitalisierter Verbreitungskarten identischer Größe für 3036 paläarktische Singvogelarten wurde eine Datenbank erstellt. Biogeographische Verbrei- tungsmuster wurden für zwei verschiedene Datensätze erstellt: (1) für alle Singvogelarten, die innerhalb der Grenzen des Untersuchungsareals als Brutvögel festgestellt wurden, (2) für Singvogelarten, die in ihrer Verbreitung auf die Untersuchungsregion beschränkt sind, also unter Ausschluss all der Taxa, die teilweise auch außerhalb der paläarktische Region vorkommen. Bezogen auf den Datensatz, der die teilweise außerhalb vorkommenden Taxa nicht berücksichtigt, ergab sich eine durchschnittliche Verbreitungsarealgröße pro Art von 238 Rasterquadraten (Rasterquadratgröße: 4,062 $\mathrm{km}^{2}$ ). Die Analyse der geographischen Verbreitung der Artenvielfalt bezüglich des Gesamtdatensatzes erbrachte verschiedene Hotspot-Regionen, die meistens in Gebirgsgegenden lagen. Der Index für die Seltenheit von Arten bezüglich ihrer Verbreitungsgebietsgröße erbrachte die gleichen Hotspot Regionen wie der für die Artenvielfalt, obwohl der Index für die Seltenheit hinsichtlich Verbreitungsgebietsgröße den zentralsibirischen Hotspot unterbewertete. Hotspots für Arten mit sehr kleinen Verbreitungsgebieten, die vom Artenvielfalt-Index unterbewertet werden, sind eine Vielzahl von Inseln. Von weit höherer Bedeutung auf der Basis des Verbreitungsgrößen-Index sind außerdem das Atlasgebirge Nordafrikas, die Jabal al Akhdar Region im Nordosten Libyens und die Ostküste des Mittelmeers. Eine Beschränkung der Analyse der geographischen Variation auf die $25 \%$ der Vogelarten mit der kleinsten Verbreitungsgröße führte zu einem weitgehend vereinfachten Muster der Hotspots.

Acknowledgments We are grateful to Dr P. H. Williams (Natural History Museum, London) for making available the WORLDMAP program, for implementing the Palearctic map, for patiently answering our many queries and assisting us with setting up and operating the program, and for reading and commenting on a draft of the manuscript. Mr J. van Arkel (IBED, University of Amsterdam) is thanked for providing the final digital artistic touch to our figures.

\section{References}

Agapow P-M, Bininda-Emonds ORP, Crandall KA, Gittleman JL, Mace GM, Marshall JC, Purvis A (2004) The impact of species concept on biodiversity studies. Q Rev Biol 79:161-179

Agapow P-M, Sluys R (2005) The reality of taxonomic change. Trends Ecol Evol 20:278-280

Anderson S (1984) Geographic ranges of North American birds. Am Mus Novit 2785:1-17

Bibby CJ, Collar NJ, Crosby MJ, Heath MF, Imboden C, Johnson TH, Long AJ, Stattersfield AJ, Thirgood SJ (1992) Putting biodiversity on the map: priority areas for global conservation. ICBP, Cambridge

Blackburn TM, Gaston KJ (1996) Spatial patterns in the geographic range sizes of bird species in the New World. Philos Trans R Soc Lond B 351:897-912

Blackburn TM, Jones KE, Cassey P, Losin N (2004) The influence of spatial resolution on macroecological patterns of range size 
variation: a case study using parrots (Aves: Psittaciformes) of the world. J Biogeogr 31:285-293

Brown JH (1995) Macroecology. University of Chicago Press, Chicago

Brown JH, Stevens GC, Kaufman DM (1996) The geographic range: size, shape, boundaries, and internal structure. Annu Rev Ecol Syst 27:597-623

Cox CB (2001) The biogeographic regions reconsidered. J Biogeogr 28:511-523

Cracraft J (1983) Species concepts and speciation analysis. Curr Ornithol 1:159-187

Cracraft J (1992) The species of the birds-of-paradise (Paradisaeidae): applying the phylogenetic species concept to a complex pattern of diversification. Cladistics 8:1-43

Cramp S (ed) (1977-1994) Birds of the western Palearctic, vols 1-9. Oxford University Press, Oxford

De Klerk HM, Crowe TM, Fjeldså J, Burgess ND (2002) Biogeographical patterns of endemic terrestrial Afrotropical birds. Divers Distrib 8:147-162

Dyuzheva TS (ed) (1973) Prirodnye zony SSSR [Natural zones of the USSR], masshtaf 1:5 000 000. Glavnoe upravlenie Geodezii i Kartografii pri Sovete Ministrov, Moskva

Gaston KJ (2003) The structure and dynamics of geographic ranges. Oxford University Press, Oxford

Gaston KJ, Blackburn TM (1997) Age, area and avian diversification. Biol J Linn Soc 62:239-253

Good R (1974) The geography of flowering plants. Longmans, London

Harrison C (1982) An atlas of the birds of the Western Palearctic. Collins, London

Hartert E (1903-1922) Die Vögel der Paläarktischen Fauna. Friedländer, Berlin

Hartert E, Steinbacher J (1932-1938) Die Vögel der Paläarktischen Fauna, Ergänzungsband. Friedländer, Berlin

Humphries C, Araújo M, Williams P, Lampinen R, Lahti T, Kotila P (1999) Plant diversity in Europe: Atlas Florae Europaeae and Worldmap. Acta Bot Fenn 162:11-21

Long AJ, Crosby MJ, Stattersfield AJ (1996) Towards a global map of biodiversity: patterns in the distribution of restricted-range birds. Global Ecol Biogeogr Lett 5:281-304

Mittermeier RA, Myers N, Gil PR, Mittermeier GC (1999) Hotspots: earth's biologically richest and most endangered terrestrial ecosystems. CEMEX, Conservation International, and Agrupacion Sierra Madre, Mexico

Mittermeier RA, Gil PR, Hoffmann M, Pilgrim J, Brooks T, Goettsch Mittermeier C, Lamoreux J, da Fonseca GAB (2004) Hotspots revisited: earth's biologically richest and most endangered terrestrial ecoregions. CEMEX, Mexico City
Molineux HGK (1930-1931) A catalogue of birds, giving their distribution in the western portion of the Palearctic Region. Fowler, Eastbourne, UK

Sangster G, Hazevoet CJ, van den Berg AB, Roselaar CS, Sluys R (1999) Dutch avifaunal list: species concepts, taxonomic instability, and taxonomic changes in 1977-1998. Ardea 87:139-165

Schmidt KP (1954) Faunal realms, regions, and provinces. Q Rev Biol 29:322-331

Sluys R, Hazevoet CJ (1999) Pluralism in species concepts: dividing nature at its diverse joints. Species Divers 4:243-256

Stattersfield AJ, Crosby MJ, Long AJ, Wege DC (1998) Endemic bird areas of the world. Priorities for biodiversity conservation. BirdLife International, Cambridge

Terborgh J, Winter B (1983) A method for siting parks and reserves with special reference to Colombia and Ecuador. Biol Conserv 27:45-58

Vaurie C (1959) The birds of the Palearctic fauna, passeriformes. Witherby, London

Vaurie C (1965) The birds of the Palearctic fauna, non-passeriformes. Witherby, London

Voous KH (1960) Atlas der Europese vogels. Elsevier, Amsterdam

Wallace AR (1876) The geographical distribution of animals, 2 vols. Harper, New York

Williams PH (2000a) WORLDMAP priority areas for biodiversity, version 4.1. Privately distributed, London

Williams P (2000b) Some properties of rarity scores used in site quality assessment. Br J Entomol Nat Hist 13:73-86

Williams PH, Gibbons D, Margules C, Rebelo A, Humphries C, Pressey R (1996a) A comparison of richness hotspots, rarity hotspots, and complementary areas for conserving diversity of British birds. Conserv Biol 10:155-174

Williams PH, Prance GT, Humphries CJ, Edwards KS (1996b) Promise and problems in applying quantitative complementarity areas for representing the diversity of some Neotropical plants (families Dichapetalaceae, Lecythidaceae, Caryocaraceae, Chrysobalanaceae and Proteaceae). Biol J Linn Soc 58:125-157

Williams PH, Burgess NB, Rahbek C (2000a) Flagship species, ecological complementarity and conserving the diversity of mammals and birds in sub-Saharan Africa. Anim Conserv 3:249-260

Williams P, Humphries C, Araújo M, Lampinen R, Hagemeijer W, Gasc J-P, Mitchell-Jones T (2000b) Endemism and important areas for representing European biodiversity: a preliminary exploration of atlas data for plants and terrestrial vertebrates. Belg J Entomol 2:21-46 